\title{
State of the Art of Land Use Planning Using Remote Sensing and GIS
}

\author{
S.D. Vikhe ${ }^{1}$, Dr. K.A. Patil ${ }^{2}$ \\ ${ }^{1}$ Research Scholar, Govt. College of Engineering, Aurangabad, Maharashtra \\ ${ }^{2}$ Associate Professor of Civil Engineering, Govt. College of Engineering, Aurangabad, Maharashtra (India)
}

\begin{abstract}
Land use planning is systematic assessment of land and water potential. Its purpose is to select and put into practice those land uses, that will best meet the need of the people while safe guarding resources for the future. Number of researchers have been established the applicability of Remote sensing and Geographical Information system to solve problems in agricultural related to land use planning. The review related to 'Land use Planning' using remote sensing and GIS is discussed in the present paper.
\end{abstract}

Keywords: Remote Sensing, GIS, Land use Planning

\section{Introduction}

Land use planning is systematic assessment of land and water potential. Its aim is to select and put into practice those land uses, which will meet the need of the people by securing resources for the future. In India, land resources have reached a critical stage due to the increasing population. An integrated approach toward conservation land resources, which also account the vulnerable environment. (Singh 2012).

Since long, natural resources are being degraded due to increase in population and poor management of land use. As per National Forest Policy (1988), one-third of the geographic area of the country is required under forest cover to maintain ecological balance and environmental stability. The forest cover of the country has been estimated to be $637.3 \mathrm{~km}^{2}$ about $19.39 \%$ of the geographic area of the country. Forestry and agriculture are two important land use, the latter competing with the former under relentless pressure of an ever increasing population which has grown from 361 million in 1951 to 955 million in 1997. To meet the requirement of food production, besides enhancing the productivity, the area under agriculture has increased from 118 million ha in 1951 to 142 million ha in 1997. (Sudhir Mahajan 2005). Land use/land-cover analysis provides the baseline data required for proper understanding of how land was being used in the past, what type of changes have occurred and are expected in the future. (Mani 2013). Land use changes are changing the hydrologic system and have potentially large impacts on water resources. Rapid socio-economic development drives land use change. (Wagner 2013). Land use/ land cover is an important component in understanding the interactions of the human activities with the environment .It is necessary to monitor and detect the Land use changes to balance a sustainable environment. (Pandian 2014).

Remote sensing and Geographical Information system provides vital tools which can be applied in the analysis at the district and as well micro level. Remote sensing provides synoptic view and multi- temporal land uses/ land cover data. ( R. K. Nigam 2000) Remote sensing and Geographical Information System based technologies may be applied to an area in order to generate a sustainable development plan. (Singh 2012).Land use planning based on land resource evaluation and spatial orientation of planning as part of GIS may ensures appropriate land allocation in order to achieve sustainable agriculture.( Andy Bhermana, et al. 2013).

\section{Research Review}

Nigam R. K. (2000) has evaluated the effectiveness of High-Resolution satellite data and computer aided GIS techniques in assessing the land use change dynamics. Study area designated Enschede City, from 1993 to 1998. Satellite images with scale 1:25000 were used of the year 1993 and 1996. A minimum delineation unit of $5 \mathrm{~mm} \times 5 \mathrm{~mm}$ was used for mapping. Digitization was done using ILWIS and created digital database for further analysis. Land use maps were crossed with each other to identify and quantify the land use changes types. Hot links and user interface was developed so that the information can be provided to the user .

Jener Fernando, et al. (2000) have described application of Universal Soil Loss Equation through GIS to predict soil loss and to assess crops .Soil erosion inventories by integrating physiography, soils, landuse/ landcover, slope map layers and land evaluation. The erosion risk map showed that $54 \%$ of the area was classified as medium to high erosion risk. Approximately $30 \%$ of sugarcane production occurs in these areas

Sudhir Mahajan, et al. (2001) have obtained the land use status of Asbwani Khad watershed using IRS-ID satellite data for 1999 Topographic analysis has been carried out using GIS software-ARC/ INFO and ARCVIEW. The altitude, aspect and slope have exhibited marked effect on land use. It has been found that of the total geographical area (85.30 sq. km) of the Ashwani Khad watershed in Himachal Pradesh, $54.53 \%$ 
constituted wasteland, 33.55\% agriculture and least I $1.92 \%$ forest. Agriculture and wasteland have been found maximum in mid altitude (1300-1500 m) and moderate slopes (13.2-26.4 degree), whereas, agriculture and forest have been maximum in flat and north aspect.

Debashis Chakraborty, et al. (2001), have studied land use indicators of a watershed in arid region, using remote sensing and GIS. The vegetation dynamics and land use/land cover types of Birantiya Kalan watershed located in the arid tracts of western Rajasthan have been characterized and evaluated Land with scrub occupied maximum area (39\% area of the watershed) in 1996 in place of crop land which was dominant (43\% of total area) in the year 1988. During eight years period, seasonal fallow land increased significantly and the areal extent of water body decreased to almost half. Vegetation vigour types have been classified into very poor, poor. moderate, good and very good categories. Moderate vigour type reduced from 62 to $27 \%$ and poor type increased from 34 to $68 \%$ during the period 1988 to 1996 . It has been observed that the ratio for vegetation vigour has been found to be 0.85 showing that the overall vegetation have not improved after the treatment.

Bisht B S and B P Kothyari (2002) have analyzed land-use change and land-cover classes in Garur Ganga watershed of Bageshwar district in Uttaranchal state. Study periods 1963-1996 and 1986-1996 were analyzed using Survey of India Topographical Sheet and LANDSAT 5 TM image bands 2, 3 and 4 using Geographical Information System. Result shows that the area under agriculture and settlement increased from 34.98 to $42.34 \%$ whereas the forest and barren land show a declining trend. Expansions of agriculture land and builtup area has been found to be maximum in the 200-1600 m elevation zone with 7-14 \% slope class. Loss of vegetation cover has observed 5.07\% between 1963-1996 and 0.81\% between 1986-1996.

Youngsug Kim, et al., (2002) have studied Runoff Impacts due to Land-Use Change in Indian River Lagoon Watershed.. The long-term hydrologic impact analysis model and a geographic information systembased soil conservation service curve number method were used to estimate average annual runoff and runoff for rainfall events with varying return periods. Land-use change on annual or long-term runoff should be considered in land-use planning. Yan Qin Zhang Jixian (2002) has integrated application of RS and GIS to agriculture land use planning. A framework of agriculture land use planning is designed based on land use suitability evaluation using integrated technologies of RS and GIS.

Yan Qin Zhang Jixian (2002) has integrated application of RS and GIS to agriculture land use planning. A framework of agriculture land use planning is designed based on land use suitability evaluation using integrated technologies of RS and GIS. Seleuk Reis, et al. (2003) have monitored land use changes by GIS and remote sensing Techniques. Trabzon's land-use changes in the last 40 years, required data was acquired for 31 square kilometer area, processed, analyzed and some queries were executed. Standard topographic maps, produced in 1960, and in scale of 1:25000, were digitized and required vector data was overlaid on it. Besides, four aerial photographs 1974, Landsat 5 TM image 1986 and Landsat 7 TM+ image 2000 were used.

Jayakumar S. and D.I. Arockiasamy (2003), have attempted to map land use / land cover and change detection analysis using remote sensing and GIS in Kolli hill, part of Eastern Ghats of Tamil Nadu,. About 467 ha increase has been observed in single crop category and about 434 ha decrease has been observed in land with or without scrub category. Majority of the area (13639 ha) is under scrubland. Lesser changes could be noticed in double crop, plantation and barren category.

Genxu Wang, et al.(2006), have studied land-cover changes and its impacts on ecological variables in the headwaters area of the Yangtze River, China. Various ecological landscape variables, such as biological productivity, soil nutrients and water source conservation capacity are identified as landscape function characteristics. A quantitative method and digital model for analyzing were used The main indication for these changes involved the intensity of the climate in this region is becoming drier and warmer, resulting in a gradual degradation of the permafrost.

Dipak Sarkar et al. (2006) have studied, soil resource appraisal towards land use planning using satellite remote sensing and GIS. Study area was Patiloniala micro watershed, district Puruliya, West Bengal. IRS ID LISS-III fused with PAN data with scale 1:12.500 used for delineating the physiographic units based on the variations in image characteristics. On the basis of physiographic variation and soil characteristics such as texture, depth, slope, erosion etc. The problem areas were identified and land use plan has been suggested for the overall development of the micro-watershed.

Ashok Mishra, et al. (2007) have studied, prioritizing structural management by quantifying the effect of land use and land cover on watershed runoff and sediment yield. In order to quantify the effect of land use/ land cover, topography, and morphology, runoff and sediment yield of a small multi vegetated watershed in a sub-humid subtropical region in India were simulated by SWAT model and were compared with measured values. Measured and model simulated estimates of runoff and sediment yield from different sub-watersheds were employed to prioritize control measures and check dam construction .

Anita K. Prakash, et al. (2007), have suggested alternative land use options in a watershed using GIS. Implementing soil and water conservation works and suggested alternative sustainable land uses based on soil and water conservation measures, groundwater prospects, land capability, and present land use/land cover in the 
area. The suggested approach is found to be very useful, as it takes into consideration basic factors necessary for the overall development and management of the watershed, and ensures stoppage of further degradation of the resources.

Tayyebi A. et al. (2008), have used remote sensing imagery, GIS-based neuro-fuzzy approach and variety of social and environmental factors for simulating land use change. Two historical Landsat imageries of Tehran Metropolitan Area with twenty year time interval and user-selected socio-economic and environmental variables have been employed in order to simulate land use change. All images were rectified and registered to Universal Transverse Mercator (UTM) WGS 1984 zone 39N. Supervised classification was used to classify the images to different land use categories. Four classes were identified as road, residential area, service centre, administrative area. Research introduces a simulation experiment on urban land use change in which a supervised back propagation neural network has been employed in the parameterization of the simulation model, while GIS is used to model and monitor land use change and perform spatial analysis on the results. The creation of the GIS based neuro-fuzzy land use change modeling is the major contribution.

Bazgeera S., et al. (2008), have carried out assessment of land use changes using remote sensing and GIS and their implications on climatic variability for Balachaur watershed in Punjab, India. Decadal changes in land use/land cover for watershed were studied using black and white aerial photographs for March 1984 on approximately 1:20,000 scale and multidate geocoded false colour composites of IRS-1D LISS-III on 1:50,000 scale for March 2002, September 2002, and May 2003 and interpreted visually to prepare land use/land cover maps for the year 1984 and 2003. The results revealed that the area under crop land, moderately dense forest, degraded forest, degraded land in hills and piedmont plains, barren land along seasonal streams has decreased, whereas, the area under settlements, dense forest, plantations, industrial use, ponds, choes and brick kilns has increased over a span of 20 years. By virtue of afforestation and forest conservation, the density of vegetation in Siwalik hills and Piedmont areas has increased. The area under moderately dense forest (1956.7 ha) and degraded forest ( 755.5 ha) got upgraded to dense forest while 755.5 ha of degraded forest changed to moderately dense forest.

Md. Abdul Halim, et al., (2008), have investigated the land-use pattern change over a period of 18 years (1988-2006) by using remote sensing and Geographical Information System, in the West Bhanugach Reserved Forest, a hill forest, in Sylhet Forest Division of Bangladesh. The images were processed using ERDAS Imagine software. Both supervised and unsupervised approaches were applied and ground control points were collected using a GPS. Maps were prepared using GIS software. Results showed that vegetation cover drastically decreased from the year 1988 to 1996 (1826 ha to 1714.85 ha), but increased gradually from the year 1996 to 2006 (1714.85 ha to 1847.83 ha) due to the initiation of co-management practice involving local communities. Change in bare land was inversely proportionate to the amount of vegetation cover changes unless any other land-uses were converted into bare land. The area of water bodies increased from the year 1988 to 1996 (307.67 ha to $379.53 \mathrm{ha}$ ), but decreased from the year 1996 to 1997, then remained invariable from the year 1997 to 2006 .

Arvind Bijalwan, et al. (2010) have carried out characterization of the land use, biomass and carbon status of dry tropical forest in Raipur district of Chhattisgarh, India using satellite remote sensing data and GIS techniques in the year of 2001-2002. The main forest types observed in the area are Teak forest, mixed forest, degraded forest and Sal mixed forest. The aspect and slope of the sites influenced the forest vegetation types, biomass and carbon storage in the different forests.

Sathees kumar P and Nisha Radhakrishnan (2010) have used remote sensing and GIS in land use planning. The different land use categories and their spatial and temporal variability in Tiruchirappalli city has been studied over a period of eight years (1998-2006), from the analysis of topographical map, IRS 1D and IRS P6 for the year 1973, 1998, 2002 and 2006 using ArcGIS and ERDAS Imagine 9.1. Based on the results of classified images, the agricultural land coverage area was reduced $7.8 \%$ from the year 1998 to 2006, while the area under settlement increased $14.7 \%$ from the year 1998 to 2006.

Arabinda Sharma et al. (2011), have carried out study of the effect of land use/ land cover change on soil erosion potential in an agricultural watershed. Universal soil loss equation was used in conjunction with a geographic information system to determine the influence of land use and land cover change on soil erosion potential of a reservoir catchment during the period 1989 to 2004. Results showed that the mean soil erosion potential of the watershed was increased slightly from 12.11 tons per hectare per year in the year 1989 to 13.21 tons per hectare per year in the year 2004. Spatial analysis revealed that the disappearance of forest patches from relatively flat areas, increased in wasteland in steep slope, and intensification of cultivation practice in relatively more erosion prone soil were the main factors contributing toward the increased soil erosion potential of the watershed during the study period.

LIU Miao, et al. (2011), have investigated the land-use and land-cover change (LUCC) in the HunTaizi River watershed, Northeast China from 1988 to 2004 based on remotely sensed images and geographic information systems (GIS) technology. Then, using the famous land-use change model of conversion of land use 
and its effects at small regional extent (CLUE-S), research simulated the land use changes under historical trend (HT), urban planning (UP) and ecological protection (EP) scenarios considering urban planning and ecological protection over the next 20 years.

LIU YaoLin, et al. (2012) have concluded that the optimized spatial allocation of rural land use can be achieved by a Particle Swarm Optimization (PSO) model in conjunction with multi-objective optimization techniques. Study focuses on Yuzhong County of Gangsu Province in China, a typical catchment on the Loess Plateau, and proposes a land use spatial optimization model. The model maximizes land use suitability and spatial compactness based on a variety of constraints, e.g. optimal land use structure and restrictive areas, and employs an improved PSO algorithm equipped with a determinant initialization method and a dynamic weighted aggregation (DWA) method to obtain the optimized land use spatial pattern.

Zhang Ying, et al. (2012) have studied, agricultural land use optimal allocation system in developing area: Application to Yili Watershed, Xinjiang Region. Subzone and a pre-allocation for each land use are added in spatial allocation module, and land use suitability and area optimization module are incorporated to constitute a whole agricultural land use optimal allocation (ALUOA) system. The system is developed on the platform Net 2005 using ArcGIS Engine (version 9.2) and C\# language, and is tested and validated in Yili watershed. Land use suitability on eight common crops is evaluated one by one using linear weighted summation method in the land use suitability model. The linear programming (LP) model in area optimization model succeeds to give out land area target of each crop under three scenarios. The results show that the land use maps with a subzone not only ensure every part has enough land for every crop, but also gives a more fragmental land use pattern.

He-Bing Hu, et al. (2012), have analysed land use change characteristics based on remote sensing and GIS in the Jiuxiang river watershed. Based on remote sensing and GIS technology, the remote sensing images from 2003 to 2009 were used to the basic data sources, to analyze the characteristics of land-use change in Jiuxiang river watershed. Results showed that watershed land use structure were changed greatly from 2003 to 2009 ; the proportion of arable land decreased from $34.86 \%$ to $19.52 \%$, whereas other types of land use increased. The area of construction land increased most rapidly, from $17.80 \%$ to $25.80 \%$.

Jeffry Swingly Frans Sumarauw and Koichiro Ohgushi (2012) have analysed curve number, land use and land cover changes in the Jobaru River Basin, Japan. Arc GIS tool to delineate river basin and sub-basin, and HEC-GeoHMS tool for estimating the CN. The result shows that from 1948 to 2005 the CN of the Jobaru River basin decreased from 53.29 to 52.03, which indicates that the land use changes in Jobaru River basin makes the land capability for reducing flood becomes better during this period. However, in the sub-basin the result is different. In mountainous sub-basin, the $\mathrm{CN}$ also decreased from 48.24 to 46.07 but in plain sub-basin the $\mathrm{CN}$ increased from 68.81 to 70.41 . Indicates that the land capability to reduce food changes better in mountainous sub-basin but become worse in the plain sub-basin.

Singh R B and Dilip Kumar (2012), have used Remote sensing and GIS for land use/cover mapping and integrated land management: case from the middle Ganga plain. Alternative land use systems and the integration of livestock enterprises with the agricultural system have been suggested for land resources management.

Kotoky, P. M. et al. (2012), have studied, changes in land use and land cover along the Dhansiri river channel, Assam by a remote sensing and GIS approach. Information on land use/ land cover change is a critical input for natural resource management policy decisions. Remote sensing data under GIS domain were utilized to evaluate the changes in land-use/land-cover (LU/LC) spanning a period of thirty three years during 1975 to 2008 along the Dhansiri river channel, Assam, India. Seven different types of land use/ land cover were categorized and out of them cropland was evident as the most important land use /land cover practices followed by dense mixed jungle in 1975 and the settlement in 2008. Significant reduction $(13.02 \%)$ in cropland area to settlement was observed. Moreover, tea garden also occupies $0.77 \%$ of the total area from cropland and open mixed jungle.

Sandra C. et al. (2013), have studied alternative land-use method for spatially informed watershed management decision making using SWAT. Modification is proposed to the Soil and Water Assessment Tool (SWAT) to enable identification of areas where the implementation of best management practices would likely result in the most significant improvement in downstream water quality. To geospatially link potential locations to individual land owners, a land-use layer that incorporated specific crops and crop rotations needed to be developed. Model results obtained using the new land-use layer is compared to those obtained using a more conventional land-use layer. Results indicate that water flow and nutrient loadings are similar at the basin outlet, confirming the overall consistency of the approach. Water flow results at upland sub basin outlets appear similar; however, nutrient loadings are different since the crop distributions in the alternative approach are more representative of actual practice in the basin.

Mani.N. and Rama Krishnan. (2013) have estimated the land use/ land cover changes in Tamil Nadu State using remote sensed data and Geographic Information System (GIS) with field verification for the objective of the study. Landsat 1973,1990 and IRS-P6 images (2008) were used. The land use/ land cover of the 
study area were classified into 7 types as followed respectively built-up, agricultural, forest, grazing land, wasteland, wetland and water bodies which adopting NRSC LU/LC classification. The research concludes that the area under built-up and agriculture has increased while the area extent of forest, grazing land, wasteland, wetland and water bodies has decreased in the study area.

Seyed Ali Jozi and Farkhondeh Ebadzadeh. (2013), applied multi-criteria decision-making in land evaluation of agricultural land use. The study was carried out to evaluate agricultural capability of a watershed located in Khuzestan; a province in southern Iran. To specify the criteria required for agricultural land evaluation, Delphi method was applied. After selecting the criteria, they were weighted using Analytical Hierarchy Process (AHP) Method. Weighted Overlay (WO) Method was also used to overlay the map layers in the GIS environment. Afterwards, sensitivity analysis was performed using Weights Sensitivity Analysis (WSA) method to show the impressibility rate of the results against a certain changes in the inputs. From study it is found that out of 6591.2 ha of the total watershed area, $50.8 \%$ has unsuitable potentiality while $27.32 \%$ has a poor suitability for irrigated agriculture. It was also determined that only $6.96 \%$ of the whole study area has a suitable potential for this purpose. It is also found that $23.38 \%$ of the total watershed area is unsuitable for rainfed farming. The results also showed that $31.78 \%$ and $19.12 \%$ of the entire study area has moderate and high potentials for rain-fed agriculture, respectively.

Wagner, P. D. S. Kumar, and K. Schneider (2013), have studied an assessment of land use change impacts on the water resources of the Mula and Mutha Rivers catchment upstream of Pune, India. Analyzed past land use changes between 1989 and 2009 and their impacts on the water balance in the Mula and Mutha rivers catchment upstream of Pune. Land use changes were identified from three rivers catchment multi temporal land use classifications for the cropping years 1989/1990, 2000/2001, and 2009/2010. The hydrologic model SWAT (Soil and Water Assessment Tool) was used to assess impacts on runoff and evapo-transpiration.

Praveen Kumar et al. (2013), have analysed land use/ land cover changes using remote sensing data and GIS of an urban area of Tirupati, India. Land use/land cover (LU/LC) changes were determined from 1976 to 2003 by using Geographical Information Systems and remote sensing technology. These studies were employed by using the Survey of India topographic map 57O/6 and the remote sensing data of LISS III and PAN of IRS ID of 2003.The study area was classified into eight categories on the basis of field study, geographical conditions, and remote sensing data. The comparison of land use/ land cover in 1976 and 2003 derived from topo-sheet and satellite imagery interpretation indicates that there is a significant increase in builtup area, open forest, plantation, and other lands. It is also noted that substantial amount of agriculture land, water spread area, and dense forest area vanished during the period of study which may be due to rapid urbanization of the study area.

Andy Bhermana, et al. (2013), have studied the combination of land resource evaluation approach and GIS application to determine prime commodities For agricultural land use planning at developed area of Central Kalimantan Province, Indonesia. The combination of some land resource evaluation can provide final results on rational land allocation and land utilization based on land capability and suitability. Land capability evaluation (LCE) and land suitability evaluation (LSE) approach rooted from USDA and FAO was used. The results of this studies showed that based on LCE approach, almost $61.94 \%$ of total areas $(9,571,231$ hectares) is arable land indicating that lands geographically have an opportunity to be developed. While based on LSE approach and GIS application, there are 3 (three) prime commodities including their geographical distribution pattern that suitable to be developed in Central Kalimantan involving wetland rubber $(7,355,390$ hectares), rice $(2,141$, 539 hectares), and oil palm (1, 722, 806 hectares).

Yangyang Liu; et al. (2013), have studied impacts of land use and climate changes on hydrologic processes in the Qingyi river watershed, China. Dramatic changes in land use and climate have occurred in the mountainous Qingyi River watershed in southwest China in the last three decades. Variable infiltration capacity,a large-scale hydrologic model, was used in this study to assess the impacts of land-use and climate changes on surface runoff, base flow, stream flow, and evapotranspiration (ET) of this watershed. The analysis of three land-use maps reveals that the conversions between forest and shrub land/grassland were the predominant land-use change over the past three decades. Hydrologic simulations show that the influence of climate change on hydrologic processes was stronger than those of land-use change.

R.K. Lallianthanga and Robert Lalchhanhima Sailo (2013), have described land use planning for sustained utilization of resources using remote sensing and GIS techniques with a case study in Mamit District, Mizoram, India. Indian remote sensing satellite data (LISS-III and Cartosat-I) had been used for generating various thematic layers like land use, slope, soil, drainage, etc. They were then integrated in conjunction with the ground and socio-economic data to evolve a comprehensive land use plan. The analysis in a GIS system helped in bringing out maps and statistics with constructive options for alternate land use plans which are expected to be both productive and sustainable.

Pandian. M, et al. (2014), have detected the changes in land use and land cover parts of Coimbatore and Tiruppur districts. The study was carried out through remote sensing and GIS approach using SOI topo 
sheets, LANDSAT imagery of 2000 and IRS-P6-LISS-III 2009. The land use/land cover classification was performed based on the Survey of India topo sheets and satellite imageries. GIS software is used to prepare the thematic maps and ground truth observations were also performed to check the accuracy of the classification. The ten year time period of $2000-2009$ shows the major type of land use change. Agricultural activities were decreased from $33.9 \%$ to $26.3 \%$, alternately fallow land was increased $43.9 \%$ to $54.5 \%$ and built-up-land was increased $0.1 \%$ to $0.3 \%$

\section{Conclusion}

In this research review paper land use planning using remote sensing and GIS is discussed in brief. Land use planning with reference to the agricultural crops has been attempted by various researchers. Integration of remote sensing data such as aerial photographs, IRS-ID, IRS ID LISS-III fused with PAN data, LANDSAT TM image, Cartosat and GIS environment such as software ARC/ INFO and ARCVIEW along with ILWIS, SWAT, ERDAS imagine, C\# language and GPS can be effectively used for land use planning. Land use planning with reference to engineering conservation measures may be planned by using RS and GIS technique.

References

[1]. Andy Bhermana, Bambang Hendro Sunarminto, Sri Nuryani Hidayah Utami and Totok Gunawan (2013). "The Combination Of Land Resource Evaluation Approach And Gis Application To Determine Prime Commodities For Agricultural Land Use Planning At Developed Area - A Case Study Of Central Kalimantan Province, Indonesia”. ARPN Journal of Agricultural and Biological Science Vol.8, (12) pp. 771-784.Note that the journal title, volume number and issue number are set in italics.

[2]. Anita K. Prakash; I. V. Muralikrishna; P. K. Mishra; and R. V. R. K. Chalam (2007).”Deciding Alternative Land Use Options in a Watershed Using GIS" Journal Of Irrigation And Drainage Engineering, (Asce) 133: pp.162-174.

[3]. Arabinda Sharma - Kamlesh N. Tiwari · P. B. S. Bhadoria (2011). "Effect of land use land cover change on soil erosion potential in an agricultural watershed". Journal of Environ Monit Assess (springer) Vol, 173: pp. 789-801.

[4]. Arvind Bijalwan, S. L. Swamy, Chandra Mohan Sharma Neeraj Kumar Sharma, A.K. Tiwari (2010). "Land-use, biomass and carbon estimation in dry tropical forest of Chhattisgarh region in India using satellite remote sensing and GIS". Journal of Forestry Research, (C) Northeast Forestry University and Springer-Verlag Berlin Heidelberg, Vol. 21(2): pp. 161-170.

[5]. Ashok Mishra \& S. Kar \& V. P. Singh (2007), "Prioritizing Structural Management by Quantifying the Effect of Land Use and Land Cover on Watershed Runoff and Sediment Yield". Journal of Water Resource Management (springer) Vol. 21, pp 1899-1913.

[6]. Bazgeera S., P.K. Sharmab, R.K. Maheya, S.S. Hundala, A. Soodb (2008). "Assessment of land use changes using remote sensing and GIS and their implications on climatic variability for Balachaur watershed in Punjab, India". DESERT Online at http://jdesert.ut.ac.ir 12, 139-147.

[7]. Bisht B S and B P Kothyari (2002). "Land-Cover Change Analysis of Garur Ganga Watershed Using GIS/Remote Sensing Technique". Journal of the Indian Society of Remote Sensing, Vol. 29, (3). Pp. 138-141.

[8]. Debashis Chakraborty, Dibyendu Dutta and Chandrasekharan H. (2001). "Land Use Indicators of a Watershed in Arid Region, Western Rajasthan Using Remote Sensing and GIS". Journal of the Indian Society of Remote Sensing, Vol. 29, (3), pp.115-128.

[9]. Dipak Sarkar S.K. Gangopadhyayand A.K., Sahoo (2006), " Soil resource appraisal towards land use planning using satellite remote sensing and GIS a case study in patiloniala Micro watershed, district puruliya, West Bengal" Journal of the Indian Society of Remote Sensing, Vol. 34, No. 3.

[10]. Genxu Wang, Yibo Wang and Jumpei Kubota.(2006) “ Land-Cover Changes and Its Impacts On Ecological Variables In The Headwaters Area of the Yangtze River, China.” Journal of Environmental Monitoring and Assessment Springer Vol. 120, pp. 361385

[11]. He-Bing Hu, Hong-Yu Liu, Jing-Feng Hao Jing An. (2012). “Analysis Of Land Use Change Characteristics Based On Remote Sensing And Gis In The Jiuxiang River Watershed”. International Journal On Smart Sensing And Interlligent Systems, Vol. 5, (4).

[12]. Jayakumar S. and D.I. Arockiasamy (2003). "Land use/Land Cover Mapping and Change Detection in part of Eastern Ghats of Tamil Nadu using Remote Sensing and GIS”. Journal of the Indian Society of Remote Sensing, Vol. 31, (4), pp.252-260

[13]. Jeffry Swingly Frans Sumarauw, and Koichiro Ohgushi (2012). "Analysis On Curve Number, Land Use And Land Cover Changes In The Jobaru River Basin, Japan”. ARPN Journal of Engineering and Applied Sciences Vol.7,(7), pp. 1819-6608

[14]. Jener Fernando Leite De Moraes, Pedro Luiz Donzeli, Francisco Lombardi Neto, André Ricardo Melo, Hélio Do Prado (2000). "Land Planning For Sustainable Development In Watersheds Using Geographical Information System". International Archives of Photogrammetry and Remote Sensing. Vol. XXXIII, Part B7. Amsterdam 2000. pp. 895-900.

[15]. Kotoky, P. M. K. Dutta and G. C. Borah (2012). "Changes in Landuse and Landcover along the Dhansiri River Channel, Assam - A Remote Sensing and GIS Approach” Journal Geological Society of India Vol.79, pp.61-68.

[16]. LIU Miao, HU Yuanman, ZHANG Wei, ZHU Junjun, CHEN Hongwei, Fengming (2011). “Application of Land-use Change Model in Guiding Regional Planning: A Case Study in Hun-Taizi River Watershed, Northeast China” Journal of Chin. Geogra. Sci. (springer link) Vol. 21(5), pp. 609-618

[17]. LIU YaoLin, LIU DianFeng, LIU YanFang, HE JianHua, JIAO LiMin, CHEN YiYun \& HONG XiaoFeng (2012). "Rural land use spatial allocation in the semiarid loess hilly area in China: Using a Particle Swarm Optimization model equipped with multiobjective optimization techniques". Science China Earth Sciences (C) Science China Press and Springer-Verlag Berlin Heidelberg Vol.55 (7): pp. 1166-1177.

[18]. Mani.N. and Rama Krishnan. (2013). Assessment of Changes In Land Use/ Land Cover In Tamil Nadu State In India Using GIS”. African Journal of Science and Research Vol 2(6): pp : 01-06.

[19]. Md. Abdul Halim1, Abdus Shahid, Mohammad Shaheed Hossain Chowdhury, Mst. Nazmun Nahar, Md. Shawkat Islam Sohel1, Nuruddin, Md. Jahangir5 and Masao Koike, (2008). "Evaluation of land-use pattern change in West Bhanugach Reserved Forest, Bangladesh, using remote sensing and GIS techniques". Journal of Forestry Research (springer) Vol. 19(3) pp. 193-198.

[20]. Pandian. M, Rajagopal.N, Sakthivel. G and Amrutha. D. (2014). "Land Use And Land Cover Change Detection Using Remote Sensing And Gis In Parts Of Coimbatore And Tiruppur Districts, Tamil Nadu, India”. International Journal of Remote Sensing \& Geoscience (IJRSG) Volume 3, Issue 1,pp. 2319-3484. 
[21]. Praveen KumarMallupattu and Jayarama Reddy Sreenivasula Reddy. (2013). “Analysis of Land Use/Land Cover Changes Using Remote Sensing Data and GIS at an Urban Area, Tirupati, India” Scientific world Journal Hindawi Publishing Corporation The Vol 02013 , pp. 107 .

[22]. K. Nigam (2000). "Application of Remote Sensing and Geographical Information System For Land Use / Land Cover Mapping And Change Detection in the Rural Urban Fringe Area of Enschede City, The Netherlands" International Archives of Photogrammetry and Remote Sensing. Vol. XXXIII, Part B7. Amsterdam 2000.

[23]. R.K. Lallianthanga, Robert Lalchhanhima Sailo (2013). "Land use planning for sustained utilization of resources using Remote Sensing \& GIS techniques: A case study in Mamit District, Mizoram, India” American Journal of Engineering Research (AJER) Volume-02, Issue (11), pp. 216-222.

[24]. Sandra C. Karcher, A. ; Jeanne M. VanBriesen, P.E., and Christopher T. Nietch, (2013). "Alternative Land-Use Method for Spatially Informed Watershed Management Decision Making Using SWAT”. Journal of Environmental Engineering (C) Asce .139:1413-1423.

[25]. Sathees kumar P , Nisha Radhakrishnan (2010). "Remote Sensing And Gis In Land Use Planning”. 11th ESRI India User Conference 2010. pp-1-7.

[26]. Seleuk REIS, Recep NIŞNCI, Bayram UZUN, Ali YALÇIN, Halilibrahim INAN and Tahsin YOMRALIOĞLU, Turkey (2003). "Monitoring Land -Use Changes by GIS and Remote Sensing Techniques: Case Study of Trabzon". $2^{\text {nd }}$ FIG Regional Conference Marrakech, Morocco, December 2-5, 2003

[27]. Seyed Ali Jozi \& Farkhondeh Ebadzadeh. (2013). "Application of Multi-Criteria Decision-Making in Land Evaluation of Agricultural Land Use". J Indian Soc Remote Sens (Springer).

[28]. Singh R B and Dilip Kumar (2012).”Remote sensing and GIS for land use/cover mapping and integrated land management: case from the middle Ganga plain” Journal of Front. Earth Sci. (springer), Vol. 6(2): pp.167-176.

[29]. Sudhir Mahajan, Pankaj Panwar And Deepak Kaundal (2001). "GIS Application to Determine the Effect of Topography on Landuse in Ashwani Khad Watershed". Journal of the Indian Society of Remote Sensing, Vol. 29,( 4), pp.243-248

[30]. Tayyebi, A., M.R. Delavar, S. Saeedi, J. Amini and H. Alinia (2008). "Monitoring Land Use Change By Multi-Temporal Landsat Remote Sensing Imagery". The International Archives of the Photogrammetry, Remote Sensing and Spatial Information Sciences. Vol. XXXVII. Part B7. Beijing2008

[31]. Wagner, P. D. S. Kumar, and K. Schneider (2013). "An assessment of land use change impacts on the water resources of the Mula and Mutha Rivers catchment upstream of Pune, India.” Journal of Hydrology and Earth System. Science., Vol. 17, pp.2233-2246,

[32]. Yan Qin Zhang Jixian (2002). "Integrated Application of RS and GIS to Agriculture Land Use Planning" Journal of Geo-spatia Information Science (Quarterly) Volume 5,(2) pp., 51- 55

[33]. Yong Liu · Yajuan Yu- Huaicheng Guo · Pingjian Yang. (2009). "Optimal Land-Use Management for Surface Source Water Protection Under Uncertainty: A Case Study of Songhuaba Watershed (Southwestern China)". Journal of Water Resour Manage (springer) Vol. (23) : pp.2069-2083.

[34]. Youngsug Kim, Bernard A. Engel, Kyoung Jae Lim Vickie Larson; and Brean Duncan (2002), “ Runoff Impacts of Land-Use Change in Indian River Lagoon Watershed" journal of hydrologic engineering (ASCE) 7(3) 245-251

[35]. Yu-Pin Lin, Nien-Ming Hong, Pei-Jung Wu. Chien-Ju Lin (2007). "Modeling and assessing land use and hydrological processes to future land-use and climate change scenarios in watershed land-use planning". Journal of Environmental Geology (Springer) Vol 53 pp. 623-634.

[36]. Zhang Ying, Zhang Hongqi, NI Dongying, Song Wei (2012)“Agricultural Land Use Optimal Allocation System in Developing Area: Application to Yili Watershed, Xinjiang Region” Chin. Geographical Science (springerlink), Vol. 22 No. 2 pp. $232-244$. 